\title{
FOGYATÉKOSSÁGGAL ÉLŐ SZEMÉLYEK FELSŐFOKÚ TANULMÁNYAIT TÁMOGATÓ TÉNYEZŐK EGY KUTATÁS TÜKRÉBEN
}

Szerzők:

Heim Anita

Lelkierő Egyesület (Magyarország)

Balázs-Földi Emese (PhD.)

Debreceni Egyetem (Magyarország)

Első szerző e-mail címe:

anitaheim4@gmail.com
Lektorok:

Soós Zsolt (PhD.)

Debreceni Egyetem (Magyarország)

Pornói Imre (PhD.)

Debreceni Egyetem (Magyarország)

...és további két anonim lektor

Heim Anita, Balázs-Földi Emese (2021): Fogyatékossággal élő személyek felsőfokú tanulmányait támogató tényezők egy kutatás tükrében. Különleges Bánásmód, 7. (4). 85-99. DOI 10.18458/KB.2021.4.85

\begin{abstract}
Absztrakt
A fogyatékossággal élő személyeket nagyobb mértékben érinti a szegénység kockázata más társadalmi csoportokhoz képest. Ennek egyik oka a fogyatékossággal élő személyek munkaerő-piaci helyzetével magyarázható, mivel foglalkoztatottságuk rendkívül alacsony, elsősorban társadalmi juttatások biztosítják létfenntartásukat. A megfelelő életminőség elérése egyik legfőbb garanciája a munkából származó jövedelem. Minél magasabb az iskolai végzettsége a munkavállalónak annál nagyobb az esélye annak, hogy érdeklődésének és képességeinek megfelelő munkát tud végezni. A fogyatékossággal élő személyek iskolai végzettsége azonban elmarad a többségi társadalom tagjaitól, felsőfokú végzettségük pedig különösen alacsony. Az esélyegyenlőség megvalósulása érdekében a fogyatékossággal élő személyek kedvezményeket, támogatásokat vehetnek igénybe továbbtanulásuk, valamint tanulmányaik során. A kutatás kvalitatív, féligstrukturált interjú módszerével tárja fel, hogy az egyetemi esélyegyenlőségi szolgáltatások hogyan segitik a fogyatékossággal élő hallgatók felsőfokú tanulmányait, támogatják-e álláskeresésüket, munkaerőpiaci beilleszkedésüket. A kutatás kiterjedt annak vizsgálatára is, hogy a családi háttér, illetve a korábbi (általános és közép-) iskolai tanulmányok hogyan járultak hozzá a megkérdezettek továbbtanulásához. A kutatási eredmények alapján megállapítható, hogy az egyetemi esélyegyenlőségi szolgáltatások eredményesen járulnak hozzá a tanulmányok sikeres befejezéséhez, illetve a további munkaerô-piaci szerepvállaláshoz. A család és a szülők, valamint az integrált keretek között folytatott tanulmányok jelentős szerepet játszanak abban, hogy a fogyatékossággal élő diákok az egyetemi továbbtanulás mellett döntenek.
\end{abstract}

Kulcsszavak: család, integráció, befogadó szemlélet, esélyegyenlőség, továbbtanulás

Diszciplína: szociológia 


\begin{abstract}
FACTORS SUPPORTING HIGHER EDUCATION OF PERSONS WITH DISABILITIES IN THE LIGHT OF A RESEARCH

Compared to other social groups, persons with disabilities are at higher risk of poverty. One of the reasons for this can be explained by the labour market situation of people with disabilities, as their employment is extremely low, their livelihood is primarily ensured by social benefits. One of the main guarantees of achieving an adequate standard of living is income from work. The higher qualifications the employee has, the higher the chance is to have a job that suits his/her interests and abilities. However, persons with disabilities tend to have lower educational qualification than members of the majority society, and their higher education is particularly low. In order to achieve equal opportunities, persons with disabilities may take advantage of allowances and subsidies in the course of their higher education as well as their studies. Using qualitative, semi-structured interviews, the research explores how services promoting equal opportunities at universities facilitate the higher education of students with disabilities, support their job search and their integration into the labour market. The research also comprised the examination of how the family background or previous (primary and secondary school) studies influenced the higher education of the interviewees. Based on the research results, it can be stated that promoting equal opportunities at universities contributes to the successful completion of studies as well as participation in the labour market eventually. The family, the parents, studying in an integrated framework play a crucial role in the decision of a student with disabilities to continue his/her studies at university.
\end{abstract}

Keywords: family, integration, inclusive approach, equal opportunities, higher education

Disciplines: sociology

\section{Esélyegyenlőség a felsőoktatásban}

A foglalkoztatottságból való kirekesztődés miatt a szegénység a fogyatékossággal élők társadalmi csoportját nagy mértékben érinti. A fogyatékossággal élő emberek esélyegyenlősége az oktatásban kiemelt jelentőséggel bír, hiszen a szellemi munka nagyobb perspektívát és jövedelmet biztosíthat számukra a fizikai munkához képest. A felsőoktatási tanulmányok több lehetőséget biztosítanak a társadalmi részvételre, illetve egy maguk választott életpálya befutására, mely a fogyatékossággal élő személyek autonómiáját, másoktól való függetlenedését is erősíti.

A Mikrocenzus, 2016 (KSH, 2018) adatai szerint a fogyatékossággal élő népesség 12\%-a nem fejezte be az általános iskolát, 38\%-a általános iskolai végzettséget, 38\%-a középfokú, és 12\%-a felsőfokú végzettséget szerzett. Ezzel ellentétben az össznépességre vonatkozó adatok szerint a középfokú végzettséggel rendelkezők aránya 45\%, a felsőfokú végzettséggel rendelkezőké pedig 17\% (KSH, 2018). A tanulmányaik befejezése után nagyobb az esélyük a munkaerópiacon való elhelyezkedésre (Andrásné Teleki, 2009), azaz a képzettségi szint emelkedésével valószínúsíthetően a gazdasági aktivitásuk is növekedik (Balázs- Földi, 2019).

Az ezredforduló környékén jelentek meg nagyobb számban fogyatékossággal élő fiatalok a felsőoktatási intézményekben, számuk a 2002/2003as tanévben 271 fö, a 2007/2008-as tanévben már 2134 fő volt (Kiss, 2014). Kiss László hivatkozik az Eurostudent $\mathrm{V}$ vizsgálatára, miszerint a felsőoktatásban tanuló hallgatók 8\%-a fogyatékossággal él, megállapítása szerint „a fogyatékossággal élők, 
illetve betegségben szenvedők közül a legnagyobb arányt, 3,3 százalékot a krónikus betegek teszik ki, ugyancsak magas, 2,9 százalékos a hosszan tartó egyéb egészségügyi problémával rendelkezők aránya. Egy százalék alatti az érzékszervi károsodással élők, valamint a tanulási nehézségekkel küzdők aránya, míg a mozgásukban korlátozottak és a mentális problémáktól szenvedők részaránya nem éri el a fél százalékot” (Kiss, 2014:118).

A 2011. évi CCIV. törvény a nemzeti felsőoktatásról 39.§ (1.) bekezdése kimondja: „Minden magyar állampolgárnak joga, hogy felsőoktatási intézményben tanulmányokat folytasson, magyar állami ösztöndíjjal, magyar állami részösztöndíjjal támogatott vagy önköltséges képzésben.” A törvény megfogalmazása szerint: „fogyatékossággal élő hallgató (jelentkezô): aki mozgásszervi, érzékszervi vagy beszédfogyatékos, több fogyatékosság együttes előfordulása esetén halmozottan fogyatékos, autizmus spektrum zavarral vagy egyéb pszichés fejlődési zavarral (súlyos tanulási, figyelemvagy magatartásszabályozási zavarral) küzd” (2011. évi CCIV. a nemzeti felsőoktatásról szóló törvény 108. § (6) bekezdése).

A 29/2002. OM rendeletben amellett, hogy a fogyatékossággal élő hallgatók kategóriáját meghatározták, a rendelet a felsőoktatási intéz-ményekbe felvételre jelentkezők körét, illetve a fogyatékosságügyi koordinátorok szerepét is sza-bályozta (Laki és Kabai, 2010). A 2005. évi CXXXIX. törvény a felsőoktatásról 39. §-a rendel-kezik az előnyben részesítésrôl, így a felvételi eljárás során elért megfelelô eredmények esetén a felsôoktatásban a mozgássérült, a látássérült, a hallássérült, valamint a súlyosan beszédhibás, az autista, illetve a diszlexiás, diszgráfiás és a diszkalkuliás személyek részesülhetnek. Az előnyben részesítés keretein belül a fogyatékossággal élő, felsőoktatásba jelentkező személyeknek, mind az alapképzési szakokon, mind a felsőoktatási szakképzéseken és az osztatlan képzéseken is 40 többletpont jár. A szabályozás 2007ben jelent meg, és egységesítette a kedvezményekben részesülő hátrányos helyzetû, illetve fogyatékossággal élő hallgatók helyzetét (Kiss, 2014). A fogyatékossággal élő hallgatónak kérelmet kell benyújtania a felsőoktatási intézmény felé, amennyiben a tanterv előírásaitól részben vagy egészben eltérő követelményeket szeretne, vagy tud teljesíteni, illetve bárminemú mentességet vagy segítséget igénybe kíván venni $(79 / 2006$. (IV.5.) Kormányrendelet a felsőoktatásról szóló 2005. évi CXXXIX. törvény egyes rendelkezéseinek végrehajtásáról).

A kérelem elbírálása után a hallgatóknak kedvezmények biztosíthatók (a 87/2015. (IV. 9.) Kormányrendelet a nemzeti felsőoktatásról szóló 2011. évi CCIV. törvény egyes rendelkezéseinek végrehajtásáról). Ugyanakkor az előnyben részesítés csak a fogyatékossággal összefüggésben állapítható meg, és nem eredményezheti az alapvetô tanulmányi követelmények alóli felmentést (A felsőoktatásról szóló 2005. évi CXXXIX. törvény 39. § (7) bekezdés c) pont). A jogalkotó célja az, hogy a fogyatékossággal élő hallgatók ne teljesítmény nélkül kapjanak diplomát, hanem ahogyan állapotuk engedi, a követelményeknek feleljenek meg, vegyenek részt az órákon, előadásokon. Ehhez az órák, előadások helyének akadálymentesnek kell lennie, illetve az órákon való kommunikációs akadályok kiküszöbölése is szükséges. Az oktatásban való részvétel elősegítése érdekében biztosított kompenzáció a fogyatékossághoz, illetve az abból adódó hátrányok leküzdéséhez kell, hogy igazodjon. A szakvélemény javaslatától függően kell a hallgatóknak mentességekben és kedvezményekben részesülniük (Vizler, 2018).

\section{Debreceni Egyetem esélyegyenlőségi szol- gáltatásai}

A Debreceni Egyetem Hallgatói Esélyegyenlőséget- és Egyenlő Bánásmódot Biztosító Szabályzata rendelkezik a fogyatékossággal élő hallgatók előnyben részesítési szabályairól, valamint azoknak az egyetemi és kari koordinátorok feladatairól, akik a fogyatékossággal élő hallgatók segitését irányítják (Net1). Szabályozza a segítségnyújtásra, 
mentességre, kedvezményekre vonatkozó kérelmekkel kapcsolatos eljárásokat, a kari bizottságok delegálásának rendjét és hatáskörét, azoknak a szolgáltatásoknak az igénybevételét, legyen az személyi vagy technikai szolgáltatás, melyeket az intézmény biztosít (Net2).

2001-ben a Debreceni Egyetemen beindították az országban akkor még egyedülálló Mentálhigiénés Programot (Berényi, 2005). E program céljaként az egyetem hallgatói számára egy átfogó lelki egészségmegőrző- és fejlesztőmodell kidolgozását túzték ki. A fent említett program küldetése az egyetem hallgatóinak életvezetési nehézségeiben való támogatása, szükség szerinti segítségnyújtása, és a jövő értelmiségének mentálhigiénés szemléletformálása. Továbbá a speciális oktatási igényú hallgatók számára segítő szolgáltatások szervezése és nyújtása, illetve a dolgozók részére az esélyegyenlőség biztosításának előmozdítása. A Mentálhigiénés Program feladatai közé tartozik mind a hallgatók, mind az egyetem dolgozói körében végzett érzékenyítés (Berényi, 2005).

2010-ben a Mentálhigiénés Programból kialakult a Debreceni Egyetem Mentálhigiénés- és Esélyegyenlőségi Központja (továbbiakban DEMEK). A DEMEK a Mentálhigiénés Program céljai köré szerveződött (Net2). A Központ által múködtetett Esélyháló Mentor hálózat célja többek közt a fogyatékossággal éló hallgatók komplex támogatása annak érdekében, hogy lehetőségük nyíljon a felsőfokú tanulmányaik sikeres folytatására. Feladata, hogy az érintett célcsoport számára elérhetőbbé tegye a felsőfokú végzettség megszerzését, valamint segítse a tanulmányi és a szociális ügyintézést. Lehetôvé teszi, hogy a fogyatékossággal élő hallgatók megismerkedjenek a lehetôségeikkel, és rendelkezzenek azokkal az ismeretekkel, amelyeket az esetlegesen felmerüló problémák esetén alkalmazhatnak, s általuk követni tudják az eljárási vagy szabályzati rendet. Fontos célja a Központ múködésének, hogy megelőzzék az érintett célcsoport hallgatóinak lemorzsolódását, illetve javítsák a kimeneti lehetőségeiket annak érdekében, hogy a végzést követően sikeresen elhelyezkedhessenek.

A Debreceni Egyetem Mentálhigiénés- és Esélyegyenlőségi Központja tanácsadást és információnyújtást biztosít az egyetemen belül és azon kívül a fogyatékossággal élő hallgatókat érintő eseményekről, szolgáltatásokról, juttatásokról, továbbá információt szolgáltat a rendelkezésre álló és folyamatosan frissített és bővített adatbázisból (Net3). Amennyiben a Központnak nem áll módjában információt szolgáltatni, úgy a hallgató részére az illetékes szakemberrel való kapcsolatfelvételben segítenek. A speciális szükségletû hallgatók diáksegítő szolgáltatást vehetnek igénybe, amennyiben mindennapi teendôjükben segítségre van szükségük. A szolgáltatást ösztöndíj ellenében a fogyatékossággal élő hallgatóval lehetőleg egy szakon tanuló hallgatótársa végzi, így óráik, szüneteik egybe esnek, a segítségnyújtás hatékonyan múködik. Ez a tevékenység szintén ellát érzékenyítő funkciót is.

A célcsoport által igénybe vehetô a jegyzetelő szolgáltatás (Net3). A fogyatékossággal élő hallgató csoporttársai közül, szintén ösztöndíj ellenében, egy hallgató az arra a célra nyomtatott, fejlécezett papírra készíti el jegyzeteit, melyeket a DEMEK irodájában lefénymásolnak, így mindkét hallgató tudja használni a lejegyzetelt anyagot. A jegyzetelő szolgálathoz szükséges képzést a Nemzeti Fogyatékosságügyi- és Szociálpolitikai Központ Közhasznú Nonprofit Kft. szervezi (Net5). Ezek mellett a következő szolgáltatásokat vehetik igénybe a fogyatékossággal élő hallgatók: fénymásolás, nyomtatás, scannelés, spirálozás, tanulást segítő technikai eszközök kölcsönzése (laptop, pendrive, akkutöltő, diktafon).

A DEMEK fontosnak tartja, hogy a mentalhigiénével, illetve a fogyatékossággal kapcsolatban a hallgatók ismeretei bővüljenek, és a szemléletük változzon. Ennek érdekében különböző értelmiségi modulokat indítottak, úgy, mint a Beilleszkedés kihívásai a mindennapokban tréninget, a Társadalom peremén kurzust, melynek keretében a társadalmi jelenségek elemzését végzik el a hallgatók film- 
alkotások segítségével. Az egyetemen a kurzusok közt megtalálható az esélyegyenlőségi tréning, melynek keretében felvehetô a csörgőlabda sportkurzus, amely kifejezetten a látássérült hallgatók részvételére számít, de más hallgatók számára is elérhetô. A Központ működtet kortárs segítô csoportot a hallgatók segítségével, Piros Pont Kortárs Segítők elnevezéssel (Net4). A csoport alapvetó tevékenysége, hogy a segítő feladatát vállaló hallgatók egyéni konzultáció és csoportos foglalkozás keretein belül találkoznak a fogyatékossággal élő és a nem fogyatékossággal élô kortársaikkal. A kortárssegítők a hallgatók számára különböző programokat szerveznek, ezzel is elómozdítva az ép hallgatók érzékenyítését a fogyatékossággal élő társaik felé.

Fontos az együttműködés más szervezetekkel annak érdekében, hogy az itt tanuló fogyatékossággal élő hallgatók integrációja könnyebben valósuljon meg, és több lehetôség adódjon a számukra elérhető szolgáltatásokban. Minden ember egyedi, minden probléma más, így az is fontos, hogy a szolgáltatásokhoz személyre szabottan juthassanak a segítséget igénylő fogyatékossággal élő hallgatók.

\section{Kutatás}

A vizsgálat célja annak feltárása, hogy az egyetemi esélyegyenlőségi szolgáltatások segítik-e a fogyatékossággal élő hallgatók felsőfokú tanulmányait, támogatják-e álláskeresésüket, munkaerő-piaci beilleszkedésüket. A kutatás kiterjed annak vizsgálatára is, hogy a családi háttér, illetve a korábbi (általános és közép-) iskolai tanulmányok hogyan járultak hozzá a megkérdezettek tovább-tanulásához.

A kutatás a Debreceni Egyetem volt és jelenlegi hallgatói bevonásával történt. A fogyatékossággal élő személyekkel a kvalitatív, félig strukturált interjúk készítése volt a legcélravezetőbb. Így amellett, hogy a fogyatékossági típusokból eredő nehézségeket kiküszöböltük, lehetôség nyílt a személyes kapcsolatfelvételre, amely lehetôvé tette, hogy a megkérdezettekkel való kommunikáció a kérdéseken és az azokra adott válaszokon túlmutasson.
Egy fó látássérült hallgató esetében a személyes kapcsolatfelvétel után a kérdések elküldése elektronikus formában történt, ezeket egy felolvasó program segítségével hallgatta meg, majd a válaszadást hangfelvétel készítésével tette meg.

A mozgásukban akadályozott válaszadók segítséget igényeltek a beszélgetés helyszínére való eljutásban. A hallássérült megkérdezetteknél a beszélgetés nem ütközött akadályokba. Hallókészülékük segítségével, illetve szükség esetén írásbeli kommunikációval megoldható volt mind a kérdésfeltevés, mind a válaszadás.

A megkérdezettek rendkívül rugalmasak voltak mind a beszélgetés időpontjával, mind a helyszínnel kapcsolatban. A vizsgált személyek a kutatás tárgyáról, témájáról felvilágosítást kaptak, ennek tudatában vettek részt benne.

\section{Minta}

A kutatás 25 fő fogyatékossággal élő személy, 11 fô jelenlegi, illetve 14 fő volt hallgató bevonásával készült. A válaszadók nemi megoszlása 17 fő nő és 8 fö férfi. Életkoruk szerint 21 és 43 év közöttiek, a megkérdezettek átlagéletkora 27,76 év. A fogyatékosság eredetét illetően a 25 fô válaszadó közül 9 fő veleszületett, 16 fő szerzett fogyatékossággal él. Fogyatékossági típus szerinti megoszlásuk a következőképpen alakul: tizenöt fő látássérült, hét fó mozgássérült, két fő hallássérült, egy fő autizmussal élô személy (1. táblázat).

1. táblázat: $A$ válaszadók nem és fogyatékeossági típus szerinti megoszlása (fö). Forrás: Sžerzók.

\begin{tabular}{|c|c|c|c|}
\hline $\begin{array}{c}\text { Fogyatékosság } \\
\text { típusa }\end{array}$ & nö/fö & férfi/fö & Össz/fö \\
\hline látássérült & 11 & 4 & 15 \\
\hline $\begin{array}{c}\text { mozgásában } \\
\text { akadályozott }\end{array}$ & 4 & 3 & 7 \\
\hline hallássérült & 1 & 1 & 2 \\
\hline $\begin{array}{c}\text { autizmussal } \\
\text { élő }\end{array}$ & 1 & - & 1 \\
\hline Összesen & 17 & 8 & 25 \\
\hline
\end{tabular}


A látássérült személyeket tekintve 8 fô vak és 7 fó gyengénlátó. A vak személyek esetében 2 fô nem használ fehér botot, így ôk a közlekedésben sok segítséget igényelnek. A hallássérült megkérdezettek hallókészülék és szájról olvasás segítségével, illetve szükség esetén írásban, zavartalanul kommunikálnak. A fogyatékosság eredetét illetően a 25 fő válaszadó közül 9 fö veleszületett, 16 fö szerzett fogyatékossággal él.

A 25 fó interjúalany közül 17 fő debreceni lakos, hét fő más városban él. A hét főből három fő a tanulmányai ideje alatt kollégiumban lakik, közülük egy fő mozgásában akadályozott, két fó látássérült hallgató. Négy fö minden oktatási napon bejár Debrecenbe. A már végzett hallgatók mind debreceniek. Az a tény, hogy a megkérdezettek között kisebb községekben élő fogyatékossággal élő hallgató nem szerepelt, illetve a más városból származó hallgatók alacsony száma rávilágíthat arra a diszkriminatív helyzetre, hogy a távol élőknek kisebb esélye van a felsőfokú tanulmányok elvégzésére, mivel ez magas költségekkel, és a családi segítségnyújtás hiányával jár. Ez a fogyatékossággal élő személyeket segítő szolgáltatások területi egyenlőtlenségének problémáját is magában hordozza.

$\mathrm{Az}$ életkorokat tekintve, a vizsgálat szempontjából fontos volt, hogy olyan képet kapjunk a munkaerő-piaci elhelyezkedés vizsgálatának aspektusából, amely rávilágít arra, hogy hogyan működtek, segítettek a hallgatóknak a szolgáltatások az elmúlt 10 évben. Hogyan fejlődtek a fogyatékossággal élő hallgatóknak nyújtott szolgáltatások az esélyegyenlőség megvalósítása érdekében, és milyen területeken lenne szükség további fejlődésre, fejlesztésre.

\section{Eredmények}

\section{A családi háttér szerepe a továbbtanulásban}

A kutatás során vizsgáljuk, hogy a családi háttér milyen szerepet játszik a hallgatók egyetemi továbbtanulásában. A családi háttér feltárása során, a válaszadók közül, a jelenlegi hallgatók mindegyike - egy fő kivételével - arról számolt be, hogy szüleivel, válás esetén egyik szülőjével él. Hét fő esetében a szülők a megkérdezettek gyermekkorában elváltak. A végzett hallgatók közül három főnek van saját családja. Az, hogy a megkérdezett jelenlegi hallgatók közül nagyrészt mindenki szüleivel, illetve válás esetén egyik szülőjével él, nem minden esetben a fogyatékossága miatt van így. A magyar társadalomban a továbbtanulás, karrierépítés, saját lakás fenntartásának nehézségei miatt jellemző, hogy a fiatalok tovább élnek a szülői házban, a leválás kitolódik, egyre később történik meg, ami a válaszadókra is vonatkoztatható.

Pisa-tesztek eredményei felhívják arra a figyelmet, hogy a család szociokulturális helyzete kiemelkedő hatást gyakorol a tanuló iskolai teljesítményére, tanulási motivációjára (Ostorics et. al., 2016). Ezt jelen kutatási eredményeink is alátámasztják. A szülók iskolai végzettségét tekintve minden válaszadóra jellemzó, hogy legalább az egyik szülő felsőfokú végzettséggel rendelkezik. Egy esetben volt rá példa, hogy a másik szülő nem fejezte be középiskolai tanulmányait, a többi családnál szakiskolát, gimnáziumot végzett szülőkről beszélhetünk. Az egyik látássérült volt hallgató így nyilatkozott a kérdésre vonatkozóan: „Mivel anyukám főiskolát végzett, és gyakorlatilag ő volt a családfenntartó, így nem volt kérdés, hogy én is továbbtanulok" (37 éves, látássérült nô). Az a tény, hogy minden válaszadó rendelkezik legalább egy felsőfokú végzettségú szülővel, arra enged következtetni, hogy a szülók magasabb szintű iskolázottsága és a család szociokulturális helyzete a gyermek fogyatékosságától függetlenül, meghatározza a képzettségi szintre irányuló elvárásokat.

Fogyatékossággal élő testvére két megkérdezett interjúalanynak van. Nem fogyatékossággal élő testvérrel a megkérdezettek közül három személy rendelkezik. A tanulmányaikkal, illetve az életvitelükkel kapcsolatos segítséget a megkérdezettek több esetben a szúk családtól, elsősorban szüleiktôl, testvéreiktől kapnak. Előfordult, bár kisebb 
mértékben, hogy a család más tagjai, nagyszülók, egyéb rokonok támogatják őket. A mozgásukban akadályozott interjúalanyok közül volt, aki részletesen elmesélte, a családi házukban milyen „infrastruktúrát” alakítottak ki, hogy megkönnyítsék a közlekedését. „A házban a helyiségek között többnyire boltíves, ajtó nélküli átjárás van. A bejárat, és a szobák ajtaja is szélesebb, mint másoknál. Két fürdőszoba van, ebből az egyik az enyém. Itt kevesebb segítség kell, és nagyobb, mint máshol egy hálószoba. Nincs emelet, és a házból a garázsba is ki tudok menni a székkel. De inkább az utcán szoktam felmenni a kocsira, ebben kell segítség (...) A szobámban nincs sok minden. Az ágyam és a beépített szekrény. Van egy asztali gépem a nappaliban, de inkább a laptopot használom, mert azt tudom a szobámban is. Egyik helyiség sem zsúfolt, a nappaliban az ebédlőasztalt is körbe tudom járni a székkel. A konyha is széles, simán be tudok menni, de nem nagyon szoktam" (22 éves, mozgássérült férfi). Egy esetben történt költözés, az egyik interjúalany baleset során történő látáskárosodását követően. A költözés mellett való döntésben leginkább az a tényező játszott szerepet, hogy a nagyszülőkhöz közelebb lakjanak, így szükség esetén tőlük is kaphatnak segítséget. „Azelőtt is Debrecenben laktunk, de a város másik végén. Most közös udvarunk van mamáékkal. Ez egy társasház, és mások is laknak itt. Egyedül azt volt nehéz az elején, hogy a mi lakásunk van az utcától a legtávolabb, de már megszoktuk. Kiskoromban, az iskola után mamáéknál voltam, ott tanultam, és csak akkor mentem haza, ha valaki hazaért" (23 éves, látássérült nő).

Ahogy fentebb említésre került, van olyan látássérült személy a megkérdezettek között, aki segítséget igényel a közlekedésben, mivel nem használ fehér botot. A többi látássérült esetében a fehér bot használata mellett, előzetes útvonaltanulással az egyedül történő közlekedés kiválóan múködik. Olyan esettel is találkozhatunk, amikor a közlekedéshez a szemüveg viselésén kívül, nincs szükség más eszközre. A mozgásában akadályozott interjúalanyok körében speciális eszközként elektromos szék, kerekesszék, múvégtag, és mankó használata is jellemző.

Arra a kérdésre, hogy hogyan élik meg a helyzetüket, rendkívül motiváló válaszok születtek. „Anyukám mindig azt mondja, hogy segítségre szorulok, és egyedül nem tudok semmit megcsinálni. Kiskorom óta ezt hallgatom, de én bebizonyítom, hogy ez nem így van (...) Diplomata leszek" (32 éves, autizmussal élő nô). Összességében elmondható, hogy az állapotukhoz mérten szembe néznek a kihívásokkal a válaszadók, és próbálják megfelelően használni erőforrásaikat a céljaik elérése érdekében.

\section{Korábbi tanulmányok}

A megkérdezettek között nagyobb arányban voltak a szerzett fogyatékossággal élő személyek, és ennek megfelelően alakult az integrált keretekben alapfokú, illetve középfokú oktatásban tanulók aránya is. A két hallássérült válaszadó az általános iskolai tanulmányait a debreceni Hallássérültek Egységes Gyógypedagógiai Módszertani Intézménye, Óvoda, Általános Iskola és Kollégiumban végezték el. Ezt követően mindketten integrált középfokú oktatást biztosító iskolában tanultak tovább. Fontos megjegyezni, hogy nem siket személyekrôl beszélünk, így arra vonatkozó következtetést, hogy az e fogyatékossággal éló személyek milyen arányban vesznek részt a felsőoktatásban, a vizsgálat segítségével nem lehet levonni.

A jelenlegi hallgatók közül egy fő szakközépiskolában tanult, tíz fó gimnáziumban végezte tanulmányait, míg a már végzett hallgatók közül két fő tett érettségi vizsgát szakközépiskolában és tizenkét fő gimnáziumban. Az a tény, hogy bár alacsonyabb számban, de kerülnek be fogyatékossággal élő személyek a felsőoktatási intézménybe szakközép-iskolában folyó tanulmányaikat követően azt bizo-nyíthatja, hogy ezek a szakközépiskolák biztosítják a szükséges feltételeket a célcsoport számára. 
Arra a kérdésre, hogy érték e hátrányok az állapotából fakadóan, nem számoltak be szélsôségesen negatív tapasztalatokról. Előfordult, hogy a társaktól gúnyos megjegyzéseket kapott egy-egy válaszadó, ám ez nem volt számottevô. A tanulás szempontjából már több esetben nyilatkoztak úgy, hogy úgy érzik, jobban is teljesíthettek volna, ha a feltételek jobban igazodnak képességeikhez. Hogy e körülmények alatt mit értettek a fent említett válaszadók, a következők mutatják: „Volt olyan, hogy egy-egy kérdést nem hallottam, ezért a feladatmegoldásba bele sem kezdtem. Az első padban ültem pedig, ezért nem mertem szólni" (36 éves, hallássérült férfi). „A matekot szinte anya tanította meg. A suliban nagyon gyorsan magyarázott a tanár" (36 éves, hallássérült férfi). Az általános iskolai tanulmányok során általában a szülői segítség volt jellemző, de több esetben vettek részt a megkérdezettek részükre biztosított fakultáción az oktatás keretein belül, illetve jellemző volt az iskolán kívüli korrepetálás formájában való tanulás is. A látássérült megkérdezettek közt az egyik már végzett megkérdezett személy nyilatkozata szerint: „Amikor az általános iskolába jártam, nem is gondoltam, hogy egyetemre fogok járni. Visszanézve, az iskola nem volt felkészülve egy látássérült gyerekre, nem is volt más, csak én" (37 éves, látássérült nô). A legpozitívabban mégis a látássérült hallgatók nyilatkoztak mind az alap-, mind a középfokú oktatási intézményekkel kapcsolatban. A mozgásukban akadályozott válaszadók leginkább a fizikai akadálymentesítés hiányáról beszéltek, amely miatt negatív benyomásukat fogalmazták meg az elôzetes tanulmányaik helyszíneivel kapcsolatban.

Arra vonatkozóan, hogy az osztály, az iskola programjain milyen mértékben vettek részt általános és középiskolai tanulmányaik során, több olyan választ kaptunk, hogy a szabadidős tevékenységekben nem vettek részt, és sok esetben saját baráti körrel nem rendelkeztek az általános iskolai tanulmányok során. „Az osztálytársaimmal nem volt gond, soha nem bántottak, de különösebben nem is foglalkoztak velem. Persze nem nagyon tudtam játszani azokat a játékokat, amiket ők, így a tanórákon kívül, nem is voltam napközis. Az órák utáni programokon így eleve nem voltam ott" (43 éves, mozgássérült nô). A középiskolában ez pozitív irányba mozdult, a válaszokból az derül ki, hogy ebben az időszakban könnyebben alakítottak ki baráti kapcsolatokat, s szívesebben vettek részt az iskola által szervezett közösségi programokban, kirándulásokban. „A kirándulásokat is úgy szervezték, hogy én is el tudjak menni, és amikor valamilyen túrára mentünk, még azt is elmondták, hogy milyen a környék. A legjobb barátnőm is az egyik régi középiskolás osztálytársam" (26 éves, látássérült nô).

Mind az általános, mind a középiskola kiválasztásánál fontos volt összességében minden válaszadónál az iskolába való eljutás kérdése, így többnyire az iskola megközelíthetősége volt a legmeghatározóbb tényezô. Egy mozgásában akadályozott megkérdezett esetében az első osztály első félévében iskolaváltás történt, mivel a szülők úgy itélték meg, hogy nem a legmegfelelőbb az oktatás a gyermekük számára az intézményben. „Sok emlékem nincs erról az időszakról, csak az, hogy sajnáltam otthagyni a barátaimat. De nyilván gyerekként nem láttam át, hogy ott nem boldogultam volna. Utólag azt mondták a szüleim, hogy a tanárok hozzáállása miatt hoztak el (26 éves, látássérült nó).

Összességében a tanulást segítő eszközök, a tanárok által nyújtott segítségadás a tananyag könnyebb elsajátításában a válaszadók véleménye szerint a középfokú oktatás intézményeiben magasabb szinten múködött, mint az alapfokú oktatást nyújtó intézményekben.

Arra vonatkozóan, hogy a továbbtanulással kapcsolatban voltak e tervek, illetve milyen lépéseket tettek, annak érdekében, hogy a kívánt irányba indulhassanak, sok esetben volt a válasz az, hogy a szülők leginkább a továbbtanulást támogatták, és az irány kiválasztásában is nagy szerepük volt. Minden esetben úgy nyilatkoztak a 
megkérdezettek, hogy tanáraik, családjuk maximálisan támogatták, segítették őket a pályaválasztás eldöntésében. „Édesapám is történelem tanár volt, nagyon sokat mesélt, már óvodás koromban is. A suliban nagyon jól ment, és szerettem is tanulni. Örült is neki, hogy ezt választom én is." (37 éves, mozgássérült férfi). A válaszadók közül négy korábbi hallgató már az általános iskolában tudta, hogy milyen munkát szeretne végezni, és jelenleg ezekben a munkakörökben dolgoznak. A gyermekeknek általában nincsenek konkrét terveik a jövőt illetően, kitartásról, és egy ésszerűen felépített tanulói életpályáról tanuskodik az, hogy a célokat sikerült elérniük, és a fogyatékosságuk nem korlátozta őket ebben.

Két esetben nyilatkoztak a válaszadók arról, hogy az osztályfőnökök személyesen mentek el otthonaikba, ahol a családdal közösen beszéltek a továbbtanulási lehetőségekről, a felvételi eljárásokra való felkészülésről. „Általános iskolában hozzám is, és minden osztálytársamhoz eljött az osztályfönök, hogy közösen beszéljük meg a családdal, hogy hova szeretnék, és hova lenne érdemes felvételizni. A közgazdasági szakközépiskolába az ô javaslata miatt nem felvételiztem. Bár nem tudom, miért akartam, soha nem voltam oda a matematikáért (29 éves, mozgássérült nô).

A fentebbiek alapján megállapítható, hogy az általános iskolákhoz képest a középiskolák befogadóbbak a fogyatékossággal élő diákokkal kapcsolatosan. Utóbbiakban nagyobb mértékben valósul meg a személyre orientált segítségnyújtás, mind a tanárok, mind a diákok szemlélete pozitívabb, így a fogyatékosság kevésbé jelenik meg akadályként, ugyanakkor a család támogató szerepe nélkülözhetetlen.

\section{Felsőfokú tanulmányok}

Arra vonatkozóan, hogy miért a Debreceni Egyetemet választották a megkérdezettek, leginkább indokként a lakóhelyükhöz való közelséget nevezték meg. Több válaszadó számára az is szerepet játszott a döntésben, hogy szülei, hozzátartozói is itt végezték egyetemi tanulmányaikat. „Anyukámmal még óvodás koromban Debrecenbe költöztünk a nagymamámhoz. Minden iskolám közel volt, nem volt gond a bejárás. A bátyám is itt tanult, de nem végezte el" (29 éves, mozgássérült nô). Volt olyan eset, ahol a továbbtanulás iránya, a kiválasztott szak, már az általános iskolai tanulmányok során megfogalmazódott, s a felkészülés is e cél köré szerveződött. „Felsőben, minden évben volt olyan osztályfőnöki óra, amikor arról beszéltünk, hogy ki, mi szeretne lenni, ha nagy lesz. Én minden évben azt mondtam, hogy történelem tanár" (37 éves, mozgássérült férfi, történelem szakon végzett, történelmet tanít). Jellemző volt az, hogy erősségeikre, képességeikre alapozva választották ki, hogy milyen szakra jelentkezzenek. „Kereskedelmi szakközépbe jártam. Elég jól ment a tanulás." (22 éves, mozgássérült férfi). A válaszadásokból úgy tűnik, hogy a fogyatékosság ténye nem befolyásolta a pályaválasztást, illetve nem merült fel akadályként a továbbtanulás során.

A tényből, hogy a területi egyenlőtlenségekből adódóan a fogyatékossággal élő személyek továbbtanulása több akadályba ütközik, mint akár az ugyanazon a kistelepülésen élő nem fogyatékossággal élő személyeké, arra következtethetünk, hogy mind az anyagi támogatások összegét, mind a családi-hozzátartozói segítség pótlására irányuló szolgáltatások körét bővíteni kell.

Arra vonatkozóan, hogy az őket illető jogokról hogyan tájékozódnak, a jelenleg is aktív hallgatók válaszaiból kiderül, hogy a beiratkozás során felvilágosítást kaptak arról, milyen szolgáltatásokat, könnyítéseket, segítséget vehetnek igénybe, és hogy kihez fordulhatnak kérdések, problémák esetén. „Első évben a beiratkozáskor volt egy tájékoztató itt, a DEMEK-ben. Akkor R. (a fogyatékossággal élő hallgatók mentora) tartott nekünk tájékoztatót. Ôt kerestem meg a kérelmekkel is." (35 éves, látássérült férfi). A végzett hallgatókat jellemzően az akkor még Támpont Iroda munkatársa informálta a lehetőségekről. 
Arra a kérdésre, hogy az egyetemi környezetet támogatónak itélik-e meg, összességében pozitív válaszok születtek, ám voltak válaszadók, akik a fizikai akadálymentesítés terén tapasztaltak hiányosságokat. „Volt olyan, hogy a székkel (elektromos) nem tudtam bemenni a terembe, mert az ajtónál túl közel voltak a padok. A fő́épületben jó, hogy van lift. Viszont amikor jövök az egyetemre, sok helyen az úton, a kocsik között közlekedek" (43 éves. mozgássérült nő). A mozgássérült hallgatók elmondása szerint nagy segítség, hogy a felvett óráikat próbálják számukra megközelíthető termekben, előadókban megtartani.

A látássérült hallgatók között volt olyan, aki szerint a követelmények nem illeszkednek a fogyatékosságukhoz, és sokkal nagyobb erôfeszítésbe kerül nekik felkészülni néhány vizsgára, mint a nem fogyatékossággal élő hallgatótársaiknak. „Az előadások közt sokat vagyok a könyvtárban, de van olyan tanár, aki küld nekem könyveket. Az a baj, hogy sok pénzt elvisz a könyvek scannelése. Jó lenne, ha a vizsgáknál ezt figyelembe vennék, vagy legalább lennének digitalizálva a vizsgákhoz az anyagok" (35 éves, látássérült férfi). A tanulást segítő eszközökkel, a laptop vagy diktafon kölcsönzési lehetőséggel, illetve a kapcsolódó szolgáltatásokkal, (jegyzetelő szolgáltatás, diáksegítő szolgáltatás) többnyire elégedettek voltak a válaszadók, ám itt is felhívták a figyelmet arra, hogy a diáksegítő tevékenységben közremúködő nem fogyatékossággal élő hallgatók esetében többször előfordult, hogy problémákba ütköztek.

A megkérdezett hallgatók válaszadásai alapján a fizikai, és esetenként a kommunikációs akadálymentesség biztosítása kifogásolható, így azok fejlesztése szükséges.

A beilleszkedésre, közösségi programokon való részvételre irányuló kérdésekre kapott válaszok sokszínúek. Volt a válaszadók között olyan, akinek a középiskolai élményeihez képest, az egyetemi beilleszkedés könnyebben ment, és a légkört otthonosabbnak, a közösséget sokkal elfogadóbbnak találták, de egyes esetekben arra is utaltak, hogy a nem fogyatékossággal élő hallgatók hozzáállása nem a legmegfelelőbb. „Van egy kialakult baráti társaságom itt. Nem csak az egyetemen találkozunk, hanem azon kívül is. Néhány régi csoporttársam jött tovább a mester szakra is." (23 éves, látássérült nő). „Hallottam olyat is, hogy nekem könnyű volt bejutni, mert kaptam plusz pontokat a fogyatékosságom miatt. Érdekes, hogy van, aki ezt is irigyli." (43 éves, mozgássérült nő). Összességében elmondható, hogy azok, akik már nem hallgatói az egyetemnek, meg voltak elégedve az itt eltöltött éveikben a közösségi élettel, és aktívan részt vettek benne. A jelenlegi hallgatók közül többen, elmondásuk alapján leginkább a tanulásra koncentrálnak.

\section{Esélyegyenlőségi szolgáltatásokkal kapcso- latos elégedettség}

A vizsgálat kérdéseire adott válaszok alapján megállapítható, hogy mind a jelenlegi, mind az egykor itt tanuló hallgatók igénybe vették a DEMEK és a Támogató Szolgálat szolgáltatásait. Legnépszerúbb a tanulást segítő technikai eszközök kölcsönzése, és a fénymásoló, nyomtató, scannelő szolgáltatások igénybevétele volt. „Az előző félévben még nem voltam fénymásoltatni, de ebben a félévben minden jegyzetet ott (a DEMEKben) fénymásoltattam." (43 éves, mozgássérült nô). „Az előadásokon nem használom a diktafont, de vannak olyan tanárok, akik az órán megengedik, hogy használjam. A többit a jegyzetelő adja ide" (23 éves, látássérült nő).

Látássérült és mozgásukban akadályozott hallgatók gyakran veszik, illetve vettek igénybe személyi segítői tevékenységet, a kísérés, az útvonaltanulás, az ügyintézésben való segítségnyújtás során. „Amikor itt tanultam, volt olyan, hogy csoporttársaim segítettek felmenni az elôadókba, de ha valamit intéznem kellett, akkor a személyi segítő - (itt a munkakör helyett a nevét említette) - kísért legtöbbször" (37 éves. mozgássérült férfi). „Az első félévben eleinte a Támogató Szolgálat autója hozott be az egyetemre, 
utána, amikor jobb idő volt, a személyi segítôvel tanultunk útvonalakat" (23 éves, látássérült nő).

A diáksegítő és jegyzetelő szolgáltatás igénybevétele különösen a már végzett hallgatók körében volt népszerû. „Az első félév nehéz volt, nem nagyon ismertem senkit. Aztán egy csoporttársam lett a diáksegítőm. Később terhes lett, de ugyanúgy jött velem fénymásolni, a tanulmányi osztályra, és segített megszerezni az anyagot. Ö még nem végzett, de most is jóban vagyunk" (29 éves, mozgássérült nő). A hallgatók többsége közepes mértékben elégedett, illetve inkább elégedett az igénybevett szolgáltatásokkal.

A jelenlegi hallgatók közül mindenki vett részt olyan egyéni konzultáción, ahol pályaorientációs tanácsadás mellett az álláskeresést pszichológiai oldalról is megközelítették. A már végzett hallgatók közül többen nyilatkoztak úgy, hogy nem tudtak róla, hogy erre lehetőség volt az alatt az idôszak alatt, amíg hallgatóként jelen voltak az egyetemen. „Akkor még nem volt ilyen tréning, vagy nekünk nem tartottak" (37 éves, mozgássérült, férfi). Az egykori és jelenlegi hallgatók között is volt olyan, aki a csoportos álláskeresési tréning lehetőségérool elmondása szerint nem tudott, illetve olyan is, aki tudott róla, de nem vett részt rajta. „A Neptunon is jött üzenet, és a Támpont (Támogató Szolgálat) is hívott. Én nem jártam, de volt erről beszélgetés év elején, amire elmentem." (23 éves, látássérült nő). A legkevesebb volt azoknak a megkérdezetteknek az aránya, akik részt vettek a tréningen. „Több ilyen tréningen voltam. Általában kreditet is kaptunk. Voltak ilyen felkészító feladatok, és próba interjúk (...) Amiken én voltam, általában szociális munkás szakosok voltak a résztvevők" (37 éves, látássérült nô).

A kérdésekre kapott válaszok alapján megállapítható, hogy a meglévő szolgáltatásokat igénylik a hallgatók, ugyanakkor nem mindegyiket ismerik, ezért népszerúsíteni kell ôket. Fontos, hogy a hallgatók ne csak tudomást vegyenek az elérhető szolgáltatásokról, hanem éljenek is a felkínált lehetőségekkel. A jelenlegi hallgatók körében a választott szakra vonatkozó kérdésekre adott válaszokból kiderül, hogy ha most jelentkeznének, mindannyian ezt a szakot választanák, ebben az intézményben. A már végzett hallgatók között voltak olyanok, akik ma már más szakot választanának.

\section{Fejlesztési javaslatok}

A válaszadók fogalmaztak meg olyan tényezőket, amelyek szerintük segítenék őket a sikeres eredmények elérésében. Egy jelenleg tanulmányait folytató látássérült hallgató szerint a digitalizált könyvek számát érdemes lenne tovább bővíteni, mivel jelentős összeget költ arra, hogy a tanulmányaihoz szükséges könyveket beszerezze. Egy mozgásában akadályozott hallgató szerint a diáksegítők munkájának ellenőrzése lenne szükséges. „A félév elején még ketten is segítettek felváltva, de az egyik már kb. a második héten szólt, hogy nem ér rá az órákra kísérni. Később volt, hogy megint kísérgetett, de látszott rajta, hogy mindig siet, és ez kellemetlen volt. Gondolom az ösztöndíj azért jól jött. Ezt is szúrni kellene valahogy" (43 éves, mozgássérült nô).

Egy Speciális Karriermenedzsment tréning indítása is felvetődött a megkérdezett hallgatók között, amit már csoportos formában integrált keretekben tartanak. Egyéni karriertanácsadáson vettek részt, ám ez izolálja a fogyatékossággal élő hallgatókat és nem segíti a nem fogyatékossággal élő emberek szemléletének változását Míg a külön, csak számukra kidolgozott Speciális Karriermenedzsment Tréning véleményük szerint többségében hasznos lenne, addig említésre került az a tény, hogy talán épp ez a különbségtétel az, ami nehezítheti a későbbi munkavállalást. Erre reagálva az egyik mozgásában akadályozott már végzett személy megfogalmazta, hogy szerinte ezt a szolgáltatást lehetne nem kifejezetten csak fogyatékossággal élő hallgatóknak biztosítani, így a nem fogyatékossággal élő hallgatók is birtokában lehetnének az itt megszerezhető ismereteknek. Annak 
kapcsán, hogy a fogyatékossággal élő hallgatók ilyen szolgáltatás nyújtásában részt vennének-e mentor szerepben, több esetben olyan válaszok érkeztek, melyek szerint szívesen dolgoznának ilyen projektben. Több esetben volt az a válasz, hogy ha egy számukra kialakított munkakörben végezhetnék a tevékenységüket, akkor szívesen bekapcsolódnának.

\section{Jövőre vonatkozó tervek}

A jövőre vonatkozó elképzeléseket a kutatás leginkább a jelenleg is hallgatói jogviszonnyal rendelkezők körében vizsgálta. A már végzett hallgatókra vonatkozóan arra irányultak a kérdések, hogy a végzés időszakában megfogalmazódott célokat milyen mértékben teljesültek, illetve sikerült-e elhelyezkedniük.

A jelenlegi hallgatók jövőterveire jellemző, hogy legtöbben mesterképzés keretében szeretnék folytatni tanulmányaikat. Volt olyan a válaszadók között, aki az oklevél megszerzését követően egy másik szak elvégzését tervezi. Csupán egy megkérdezett válaszában szerepelt az, hogy a jelenlegi tanulmányait befejezve szeretne elhelyezkedni, és már azt is tudja, hogy melyik munkahelyen fog munkát vállalni. Arra a kérdésre, hogy a nyílt munkaerő-piacon látnak-e esélyt a munkavállalásra, eltérő válaszok születtek. Volt olyan, aki úgy vélte kapcsolatai segítségével el fog tudni helyezkedni, épp ezért választ a végzés után egy másik szakot is, hogy a kívánt munkakör betöltéséhez megfelelő végzettséggel rendelkezzen. Ahogyan a nem fogyatékossággal élő hallgatók között, ebben a körben is találkozhatunk azonban olyan személlyel, akinek egyelőre nincsenek kialakult tervei, az egyetemi élet foglalja le jelenleg. Akik tisztában vannak vele, hogy milyen területen, milyen munkahelyen szeretnének elhelyezkedni, azok a személyek tudtak leginkább arra a kérdésre válaszolni, hogy az adott munkavégzéshez fognak e segítséget igényelni. A munkahelyre való odajutásban jellemzó, hogy a válaszadók szerint nem lesz szükségük segítségre. A munkavégzéshez szükséges eszközök közül a látássérült hallgatók felolvasó programot, zavartalan munkahelyen belüli útvonalakat, és nem utolsó sorban, az elfogadó kollektívát jelölték meg. A válaszadók közt volt olyan, aki szülei segítségére továbbra is számít.

A 14 fő volt hallgató közül négy állandó munkahellyel rendelkezik, három fó a végzettség megszerzése óta nem tudott elhelyezkedni. Esetükben egy, három és három év álláskeresési időszakról beszélhetünk. Két fő nem a végzettségének megfelelő munkakört tölt be, de elégedett a munkájával. Három fó jelenleg pályázat keretében foglalkoztatott, határozott idejű szerződéssel rendelkeznek. Két fó jelenleg nem dolgozik, de a tanulmányaik befejezése óta mindkettőjüknek volt már munkahelye. Egyikük pszichológia szakon végzett, ôt pályázatfigyelô munkakörben egy pályázat keretein belül foglalkoztatták, tehát nem a szakmájában. Egy fó informatikai-könyvtáros szakon végzett, neki sikerült a szakmájában elhelyezkednie.

A 14 fô már végzett hallgató közül három válaszadónak van saját családja. Ök saját háztartásban élnek. A magánéletre vonatkozó kérdések tekintetében, a családalapítás gondolata kisebb mértékben fogalmazódik meg a válaszadók körében. Elsősorban a nők voltak azok, akik a jövőben szeretnének saját családot, fogyatékossági típustól függetlenül.

\section{Következtetések, javaslatok}

A tanulmány bemutatta az egyetem által nyújtott szolgáltatásokat, illetve a fogyatékossággal élő hallgatók számára biztosított előnyben részesítési intézkedéseket, valamint fogyatékossággal élő személy körében végzett félig strukturált interjúk elemzésével, a különböző életutak mentén a felsőoktatásban nyújtott szolgáltatások eredményességét derítette fel. A kutatás vizsgálta azt is, hogy mennyire befolyásolja a fogyatékossággal élő hallgató továbbtanulását, későbbi elhelyezkedését az, hogy milyen közoktatási intézménybe járt, milyen családi háttérrel rendelkezett. 
A családi háttér, mint támogató közeg, valamint a szülők iskolai végzettsége kiemelkedően fontos a fogyatékossággal élő személyek továbbtanulásában. A válaszadók mindegyike esetében, legalább az egyik szülő felsőfokú végzettséggel rendelkezik, s összességében a továbbtanulást támogató családi háttér jellemezte minden válaszadó helyzetét. Ez arra enged következtetni, hogy a szülők végzettsége, és a végzettségre irányuló szülői elvárások meghatározták a megkérdezettek továbbtanulását, s annak irányát. A családi háttér, a támogató közeg nagy szerepet játszik az egyéni életutak alakulásában.

Jelen vizsgálat arra is rámutat, hogy az integrált keretek között tanuló fogyatékossággal élő diákok nagyobb eséllyel kerülnek be a felsőoktatási intézményekbe, mint a szegregált keretek között tanuló fogyatékossággal élő személyek. A kutatásban részt vevő hallgatók mindegyike integrált középfokú oktatási intézményben tanult. A megkérdezettek között két olyan személy volt, akik az alapfokú tanulmányaikat speciális iskolában folytatták, viszont a középfokú oktatási intézményben már integrált keretek között tanultak. Ennek alapján arra következtethetünk, hogy valószínúleg a szegregált iskolák nem támogatják kellőképpen a továbbtanulást, és a felsőfokú tanulmányokat. A középfokú oktatás tekintetében fontos megemlíteni, hogy a megkérdezett 25 fó fogyatékossággal élő személy közül három fö, szakközépiskolai tanulmányokat követően tanult tovább az egyetemen. Tehát a szakközépiskolák is megfelelő segítséget tudnak nyújtani a tanulók továbbtanulása szempontjából, s nem szenvednek hátrányokat az innen felsőoktatásba jelentkező fogyatékossággal élő hallgatók.

A kutatás eredményei rávilágítanak az egyetem fogyatékossággal élő hallgatóinak nyújtott szolgáltatásainak fontosságára, a sikeres tanulmányi eredményekben játszott szerepére és arra, hogy eredményesen támogatják az egyetemi közösségi életben való részvételt. A megkérdezett jelenlegi, és már végzett hallgatók is elégedettek voltak a szolgáltatásokkal, és könnyebben boldogulnak általuk.

A szolgáltatások közül a legnépszerúbb a tanulmányi ügyintézésben való segítségnyújtás, az útvonaltanulás, a személyi segítés és tanulást segítő eszközök kölcsönzése. Kisebb mértékben vettek részt egyéni konzultációkon, mely keretein belül az állapotukból adódó mentális nehézségek feldolgozásában kaptak pszichológiai segítséget. A közösségi ellátások által nyújtott szolgáltatások közt a szabadidős programok voltak inkább népszerűek.

A látássérült és mozgássérült hallgatók gyakran vették igénybe a Jegyzetelő és a Diáksegítő szolgáltatást. A Diáksegítő szolgáltatásban az érintett hallgatók véleménye szerint a diáksegítő tevékenységet folytató hallgatók munkájának irányítása, ellenőrzése nagyobb figyelmet igényelne. A látássérült hallgatók tanulmányait segítené, ha nagyobb mennyiségben tudnának hozzájutni digitalizált könyvekhez. A mozgássérült hallgatókkal készített interjúk rávilágítottak arra a tényre, hogy a fizikai akadálymentesség nem száz százalékosan biztosított, ám ezt a problémát az őket körülvevő csoporttársak, intézkedések segítségével kiküszöbölték. Az eredmények alapján megállapítható, hogy az álláskeresést, a munkaerőpiacon való elhelyezkedést segítő szolgáltatásokat kevésbé ismerik, illetve veszik igénybe a hallgatók.

A kutatás eredményeire alapozva, javasolható a fogyatékossággal élő hallgatóságot segítő szolgáltatások fejlesztése. A munkavállalás esélyét novelhetné a támogatott foglalkoztatási modell beépítése a szolgáltatási tevékenységbe vagy a sorstárs munkaerő-piaci mentor alkalmazása. Ez utóbbi azt jelentené, hogy a már végzett, a nyílt munkaerőpiacon sikeresen elhelyezkedett fogyatékossággal élő fiatalok, mint munkaerő-piaci mentorok segítik az álláskeresésben és az elhelyezkedésben fogyatékossággal élő hallgatótársaikat. A mentorok, akik már rendelkeznek tapasztalattal, információkkal és tanácsokkal tudják ellátni a fiatalabb generációt. Új szolgáltatási elemként érdemes lenne az úgynevezett Speciális Karriermenedzsment 
tréninget is beépíteni a DEMEK tevékenységébe. Ez a szolgáltatás az Eötvös Lóránd Tudományegyetemen elérhető, és lényegében a már jelenleg is működő álláskeresési tréning továbbfejlesztését jelentené (Net6). A kurzus keretében a hallgatók megismerkednének az álláskereséssel és annak folyamatával. Viszont az általános ismeretek megszerzése (az önéletrajz típusainak ismerete, formai, tartalmi követelményei, a motivációs levél formai, tartalmi követelményei, az állásinterjú típusainak megismerése, formai, tartalmi jellegzetességei) mellett, megismernék a megváltozott munkaképesség fogalmát, a vonatkozó jogi szabályozást, illetve a minősités menetét és kategóriáit, valamint a munkáltatók érdekeltségeit a fogyatékossággal élő, megváltozott munkaképességú munkavállalók foglalkoztatásában. Az álláskeresési tréning ez irányban történő továbbfejlesztése a fogyatékossággal élő hallgatók szempontjából azért lehetne célravezetőbb, mert nagyobb figyelmet fordíthatnak az álláskeresésben az egyéni speciális helyzetre, igényekre. A megkérdezett személyek véleménye szerint, a szolgáltatás eredményesebb lenne, ha a nem fogyatékossággal élô és fogyatékossággal élő hallgatók közösen vehetnének részt a kurzuson, hiszen mindamellett, hogy a munkaerópiaci ismeretek mindenki számára hasznosak, egymás megismerését és elfogadását is elősegítené. A fogyatékossággal élő hallgatók által igénybe vehetô szolgáltatások, akkor múködhetnek a leghatékonyabban, ha azok kidolgozásában ôk is részt vehetnek, így a tartalmi elemek nagyobb mértékben épülhetnek rá tényleges szükségleteikre.

\section{Irodalom}

Andrásné Teleki Judit (2009): Fogyatékossággal élō ballgatók a felsöoktatásban, Tájékoztató. Oktatási és Kulturális Minisztérium

Balázs-Földi Emese (2019): A fogyatékossággal élő személyek munkaerôpiaci szerepvállalása és a felsőfokú iskolai végzettség összefüggései. Munkaügyi Szemle, 62. (3.). 50-65.
Berényi András (2005): A Debreceni Egyetem Mentálhigiénés Programja. Mentálbigiéné és Pszichoszomatika folyoirat, 6. (2.).141-146.

Kiss László (2014): Fogyatékkal élő és krónikus beteg hallgatók a felsőoktatásban. Felsôoktatási Mühely 1. 117-128.

KSH (2018): Mikrocenzus 2016, 8. A fogyatékos és az egészségi ok miatt korlátozott népesség jellemzői, Budapest, 2018. https://www.ksh.hu/docs/hun/xftp/idoszaki/ mikrocenzus2016/mikrocenzus 2016 8 .

Laki Ildikó, Kabai Imre (2010): Fogyatékossággal éló fiatal felnốttek társadalmi integrálódásának esélyei és lehetöségei a mai Magyarországon. Budapest, L'Harmattan kiadó

Ostorics László, Szalay Balázs, Szepesi Ildikó, Vadász Csaba (2016): Pisa2015. Összefoglaló jelentés. Oktatási Hivatal. Budapest.

Vizler Vanda (2018): A fogyatékossággal élő hallgatókra vonatkozó rendelkezések, jogszabályok és az állami felsőoktatási intézmények szabályzatai, „SZUMMA -Felsőoktatási Fogyatékosságügyi koordinátorok országos kialakítása" címû FKH2016/1 azonosítószámú projekt Zarótanulmány 114-122. https://szummahalo. $\mathrm{hu} /$ sites/default/files/szumma eljarasrend.pdf (2019.02.02. 14:41)

2005 évi CXXXIX. törvény A felsőoktatásról

2011. évi CCIV. a nemzeti felsőoktatásról szóló törvény

79/2006. (IV. 5.) Kormányrendelet a felsőoktatásiról szóló 2005. évi CXXXIX. törvény egyes rendelkezéseinek végrehajtásáról

87/2015. (IV. 9.) Kormányrendelet a nemzeti felsőoktatásról szóló 2011. évi CCIV. törvény egyes rendelkezéseinek végrehajtásáról

Net1: A Debreceni Egyetem Hallgatói Esélyegyenlőséget és Egyenlő Bánásmódot Biztosító Szabályzata $\quad \underline{\text { https://econ.unideb.hu/sites }}$ $\angle$ default/files/upload documents/A\%20DE $\%$ 20 Hallgat $\% \mathrm{C} 3 \% \mathrm{~B} 3 \mathrm{i} \% 20 \mathrm{Es}^{2} \% \mathrm{C} 3 \% \mathrm{~A} 9$ lyegyen $1 \%$ C5\%91s $\%$ C3\%A9get $\% 20 \% \mathrm{C} 3 \% \mathrm{~A} 9 \mathrm{~s} \% 20$ Egyen $1 \% \mathrm{C} 5 \% 91 \% 20 \mathrm{~B} \% \mathrm{C} 3 \% \mathrm{~A} 1 \mathrm{n} \% \mathrm{C} 3 \% \mathrm{~A} 1 \mathrm{sm} \% \mathrm{C} 3 \%$ 
B3dot $\% 20$ Biztos $\%$ C $3 \%$ ADt $\%$ C $3 \%$ B3 $\% 20$ Szab \%C3\%A1lyzata\%2020160428.pdf (2019.10.13. 12:38)

Net2: A Debreceni Egyetem Mentálhigiénés és Esélyegyenlőségi Központ (DEMEK) tevékenysége. http://www.feta.hu/sites/default /files/debreceni_egyetem_mentalhigienes_es_e selyegyenlosegi_kozpont_demek.pdf

Net3: A Debreceni Egyetem Mentálhigiénés - és Esélyegyenlőségi Központ szolgáltatásai http://www.lelkiero.unideb.hu/hu/eselyegyenl osegi-szolgaltatasok
Net4: Piros Pont Kortárssegítők http://lelkiero. unideb.hu/hu/kortars-segites 2020.01.24.

Net5: Jegyzetelő Szolgálat https://fszk.hu/kepzes/ mindennapi-hosok-az-iskolapadban-avagy-ajegyzetelo-szolgaltatas/2020.02.01.

Net6: Eötvös Lóránd Tudományegyetem Speciális Karriermenedzsment https://karrierkozpont. elte.hu/specialis-karriermenedzsment-azallaskereses-lepesei-specialis-karriermenedzs ment-i/ (2019. 10.12.) 